\title{
Kidney transplant outcomes in single center of Mongolia
}

\author{
Javkhlantugs Dondog, Saruultuvshin A, Bayan-Undur D, Od-Erdene L, Batsaikhan B, Erdenesaikhan M, Ganbold G, \\ Sarantsetseg J, Oyunbileg B, Khishgee L
}

Kidney Transplantation Team, First Central Hospital of Mongolia, Ulaanbaatar, Mongolia

Background: Kidney transplantation (KT) is the optimal treatment for patients with end-stage renal disease (ESRD). Living donor (LD) KT had the superior results for the recipient, but in recent years, the number of patients for deceased donor (DD) KT is increasing worldwide. This study was carried out to determine survival outcomes between the recipients in LDKT and DDKT.

Methods: Data were collected retrospectively for 128 KT recipients including 101 LDKT and 27 DDKT recipients, performed from 2016 to 2021 in the organ transplant center of First Central Hospital of Mongolia. Demographics, delayed graft function (DGF), 1- and 5-year patient and KT survival for the LD group were compared to the DD group using one way analysis of variance and Kaplan-Meier tests. DGF was defined as the need for at least one dialysis session in the first week after KT.

Results: Mean age of the recipients was $37.4 \pm 10.4$ years and male gender was dominant among them. Mean age of the donors was $42.8 \pm 10.1$ years and donor gender ratio was 1:1. The main primary disease for ESRD was glomerulonephritis (87.5\%). Mean hemoglobin of the recipients was $10.5 \pm 1.5 \mathrm{~g} / \mathrm{dL}$, albumin $39.7 \pm 5.3 \mathrm{~g} / \mathrm{L}$, total protein $64.4 \pm 9.8 \mathrm{~g} / \mathrm{L}$, and serum $C$ reactive protein $8.2 \pm 11.9 \mathrm{mg} / \mathrm{dL}$. The incidence of DGF in LD and DD group were $3(2.9 \%)$ and $8(29.6 \%)$, respectively $(P<0.001)$. Human leukocyte antigen mismatches (4-6) in LD and DD group were $19(27.9 \%)$ and $10(55.6 \%)$, respectively $(P<0.05)$. One- and 5-year overall KT survival were $94 \%$ and $81 \%$, and overall patient survival were $98 \%$ and $88 \%$, respectively. KT 1 - and 5 -year survival for LDKT were $95 \%$ and $81 \%$, for DDKT were $88 \%$ and $72 \%$, respectively $(P=0.148)$. One- and 5 -year patient survival for LDKT were $100 \%$ and $87 \%$, for DDKT were $88 \%$ and $88 \%$, respectively $(P=0.136)$.

Conclusions: We need to further study influencing factors on kidney transplant outcome and its relationship.

Corresponding author: Javkhlantugs Dondog

E-mail: dr.dondog@gmail.com

(c) The Korean Society for Transplantation

This is an Open Access article distributed under the terms of the Creative Commons Attribution Non-Commercial License (http://creativecommons.org/licenses/by-nc/4.0/) which permits unrestricted non-commercial use, distribution, and reproduction in any medium, provided the original work is properly cited. 